\title{
A Study of Investment Behavior of Households in Virudhunagar District
}

\author{
M. Selvakumar ${ }^{1 *}$ and N. Manicka Mahesh ${ }^{2}$ \\ 'PG and Research Department of Commerce, Ayya Nadar Janaki Ammal College, Sivakasi, India \\ ${ }^{2}$ Department of Management Studies, Sri Krishna College of Engineering, Coimbatore, India
}

\begin{abstract}
Investment of hard earned money is a crucial activity of every human being. Investment is the commitment of funds which have been saved from current consumption with the hope that some benefits will be received in future. Thus, it is a reward for waiting for money. Savings of the people are invested in assets depending on their risk and return demands, safety of money, liquidity, the available avenues for investment, various financial institutions, etc. On the other hand, the savings provide capital to industry, economic development to the country. In developing country like India, household savings is the major source of capital for economic activities. The study helps to understand the knowledge and behavior of households, the major provider of funds to economic activities of the country. Hence, a study of investment behavior of households has made with the objective of understanding the level of knowledge of households about investment.
\end{abstract}

Keywords: Investment, Behavior, Risk, Households, Return

\section{Introduction}

In today's scenario, money plays an important role in one's life. In order to overcome the problems in future one has to invest his or her money. Investment may be defined as sacrifice of certain present value for some uncertain future value. In other words, investment means the purchase of a financial product with an expectation of future returns.

Investors have different mindset when they decide about investing in a particular avenue. Every individual wants his saving to be invested in most secure and liquid way. However, the decision varies for every individual depending upon their risk aptitude. Investment behavior is related to activities of individual investors regarding searching, evaluating, acquiring, reviewing the investment products and if necessary, disposing such investment products. Investment behavior reveals how the individual investor allocates the surplus financial resources to various instruments available.

*Email: professorselvakumar@gmail.com
Investment behavior is the behavior of the investors while investing in any investment options. In other words, what an investor look while investing in the investment avenues. There are various investment options available in the market. People prefer to invest in particular investment options according to a purpose, need, with certain objective in mind. Various objectives behind investment in particular investment avenues are retirement planning, tax saving, children marriage, future obligation, children insurance, improve standard of living, acquisition of asset, supporting parents, health insurance, income regularity and many more.

People prefer to invest in safe and secure investment avenues. People with different age group prefer to invest in different investment avenues. Young people prefer to invest for income regularity, future obligation and others. Old age people prefer to invest for retirement planning, children education, children marriage 
and for other obligations. Males and females prefer to invest in different investment avenues. Females prefer to invest in safe investment such as gold, Provident Fund and many more. Males prefer to invest in equity shares, debentures, mutual funds, precious metals, different commodities, and others. (Nagy, R. A. and R. W. Obenberger, 1994).

Investing is a serious subject that can have a major impact on investor's future well-being. Virtually everyone makes investments. Investors have a lot of investment avenues to park their savings. The risk and returns available from each of these investment avenues differ from one avenue to another.

When it comes to investing, the volume of facts and information available can be incredibly time consuming to wade through and for many individuals it is confusing. In India, many investment avenues are available where some are marketable and liquid, while others are non-marketable and some of them are highly risky while others are almost riskless. The investor has to choose avenue, depending upon his specific need, risk preference and expected returns. Therefore, the behavior on investment and its avenue is very important to make the investment risk free and at the same time profitable. As the household is the major source of finance, this study analyses the behavior of households on investments.

\section{Review of Literature}

A number of research studies have been undertaken in India and abroad to identify the investment behavior of individual and households. They are as follows:

Nagy and Obenberger (1994) examined factors influencing investor behavior. They had developed a questionnaire that included 34 factors such as expected corporate earnings, diversification needs, feelings for firm's products and services, past performance of stocks, past performance of their own portfolio, stock broker recommendations etc. Their findings suggested that classical wealth-maximization criteria are important to investors, even though they employ diverse criteria when choosing stocks for investment. Contemporary concerns such as local and international operations, environmental track record and the firm's ethical posture appear to be given only cursory consideration. The recommendations of brokerage houses, individual stock brokers, family members and co-workers go largely unheeded. Many individual investors discount the benefits of valuation models when evaluating stocks. Information has been one of the most important component in determining the behavior of individuals. In case of their behavior in stock market, it becomes even more critical to access and incorporate into their decision making updated information included in financial reports, periodical press releases, and media coverage etc. Researchers have acknowledged the significance of information factor in individual investment behavior.

Gupta et al. (2001) studied the Indian household investors' preferences, future intentions and experiences and found that bonds were regarded as an investment for the retired people but that did not have much appeal for young people. The market penetration achieved by mutual funds was found to be much lower than equity shares for all age classes.

Kim and Nofsinger (2003) studied individual investors in the Japanese markets and examine their behavior and performance. They used the market level data and found that Japanese investors own risky and high book-to-market stocks, trade frequently, make poor trading decisions and buy recent winners. Further, these behaviors and characteristics appear to vary depending on the bull or bear market conditions. They observe that it is primarily during a bull market where individuals tend to hold high book-to-market stocks, as opposed to a bear market where they exhibit an inclination towards high beta stocks. Overall the poor performance by individual investors can largely be explained by this tendency to hold value stocks during advancing markets and high risk stocks during declining market. They conclude that these behaviors reveal at the market level also represents important findings and hence, become one of the important bases of our study of individual investors in India.

Nasir and Khalid (2004) concluded that savings in Pakistan showed a positive response to GDP growth and government's current expenditure while it remained insensitive to interest rates. 
Gupta and Jain (2008) on the basis of an all-India survey of 1463 households found the preferences of investors among the major categories of financial assets, such as investment in shares, indirect investment through various types of mutual fund schemes, other investment types such as exchange-traded gold fund, bank fixed deposits and government savings schemes. The study provides interesting information about how the investors' attitude towards various investment types are related to their income and age, their portfolio diversification practices, and the over-all quality of market regulation as viewed by the investors themselves.

Davar and Gill (2009) investigated the underlying dimensions in the selection of different investment avenues for the households. The results of the study revealed emphasis on familiarity, satisfaction, opinion and demographic dimensions for all investment avenues.

Abhijeet Chandra and Ravinder Kumar (2011) revealed some psychological axes, such as conservatism and under confidence, which are consistent with the prior literature to some extent; but there are some contrary behavioral axes reported by the multivariate analysis such as prudence and precautious attitude and informational asymmetry which are not yet considered in prior literature in growing economies, particularly in Indian context. These psychological components seem to be influencing individual investors' trading behavior in Indian stock market.

Geetha and Ramesh (2011) studied the Indian's behavior about investment preferences. The data for their study was collected with the help of questionnaire and their total sample size was 210 respondents. They studied the effect of demographic variables on investment preferences. The study found that people were not aware about all the investment options available to them and they lack knowledge about securities.

Shanmugasundaram and Balakrishnan (2011) conducted research to analyze the factors influencing the behavior of investors in capital market. They concluded that demographic factors influence the investors' investment decisions.
Chaturvedi and Khare (2012) examined the investment pattern and awareness of the Indian investors about different investment instruments. The results suggest that age, education, occupation and income level of the individual affects their investment behavior. Awareness of respondents towards traditional investment options is much higher than that for corporate securities, mutual funds, equity shares and preference shares. They also identified the factors which contribute to investor awareness. They found that occupation, education and income level affects the awareness level of investors towards various investment avenues.

Josiah Aduda, Odera Eric Oduor and Mactosh Onwonga (2012) found that there were varied behaviors and financial performance of individual investors in trading shares of companies listed at the Nairobi Stock Exchange, Kenya. Some investors exhibited rational behavior in making their investment decisions. On the contrary, there were investors who were poised to realize negative results due to irrationality and herding behavior.

Mandeep Kaur and Tina Vohra (2012) suggest that understanding the individual investor behavior could be of great help in order to explain the stock market anomalies and to help the policy makers, the investment agencies, the researchers as well as managers of firms to prepare themselves to respond to the varying moods of an investor.

Murithi Suriya, Narayanan and Arivazhagan (2012) revealed that female investors dominate the investment market in India. According to their survey, majority of the investors are found to be considering two or more sources of information to make investment decisions. Most of the investors discuss with their family and friends before making an investment decision.

Suman Chakraborty and Sabat Kumar Digal, in their study shows that, objective to saving is significantly influenced by demographic factors such as age, occupation and the income level of investors. Their study exhibits the saving habit of retail investors across the different income levels. Savings is a habit specially embodied into women. It was found that female investors tend to save more in a disciplined way than the male investors. 
Lubna Ansari and Sana Moid (2013) have revealed that investing activity of young professionals is independent of gender but dependent on Income and Age. According to the study it can be inferred that majority of investors invest for growth and additional income and the major factor that guides their investment decision is risk factor which means that investors mostly are risk averse.

Puneet Bhushan (2014) examined the awareness level and investment behavior of salaried individuals towards financial products. Results of the study suggest that respondents are quite aware about traditional and safe financial products whereas awareness level of new age financial products among the population is low. Also majority of the respondents park their money in traditional and safe investment avenues.

All these studies give the background and basis for the current study. From literature the researcher understood how the investment behavior is important to the households.

\section{Statement of the Problem}

Savings or Investments are acknowledged as the powerful tools in the alleviation of the poverty. Inflation is constantly increasing the cost of goods and services and eating into the value of household's income and wealth. Households need to save money and invest it well so that the value of every rupee is augmented. Investing selectively, allows the investors to enjoy tax benefits. By investing wisely, investors can improve their standard of living and create wealth for the future. Investing even a small amount can produce considerable rewards over the long term. Due to the technological developments, now investors are blessed with different investment channels. But, investors need to make the wise investment decision of where to invest and how much to invest. For that the investor needs to know the investment options thoroughly. But, there will be the confusion among the people for the selection of best investment avenue. Because each investment avenue presents different types of return and risk level. Investor needs to understand the investment objectives. Investment must be made to suit the need of investor. That is the major problem of investors. In this context the present study becomes highly essential.

\section{Scope of the Study}

This study analyzes the investment behavior of household in Virudhunagar District. This study also explores the investor's awareness and attitude towards the various investment avenues and their investment preferences.

\section{Objectives of the Study}

1) To Study different types of Investment avenues in Virudhunagar District.

2) To Rank various Investment types based on household investor's preference.

3) To identify the primary considerations for investment of households.

4) To analyze the effect of investor's personal factors towards their investment considerations.

5) To identify the reasons for attractiveness of chits as an investment option among the households.

6) To identify the reasons for non-attractiveness of Shares as an investment option among the households.

\section{Methodology of the Study}

The data required for the study has been collected from both primary and secondary sources. The primary data have been collected from the respondents through a well designed interview schedule. The interview schedule has been designed keeping in view the objectives of the study. The secondary data relevant to the study was collected from various sources such as text books, magazines, research articles published in standard journals, dissertations and websites.

\section{Sampling Design}

Since the number of households in the district is very high, the collection of data from the entire population is not feasible. So researcher has decided to use the sampling technique. Willingness of the respondents is considered essential for the study. So the researcher has 
decided to use the Convenience Sampling method to choose sample respondents on the basis of Willingness of the respondents and the convenience of researcher. The researcher has decided to use the sample size of 200 , based upon time and other constraints. So 200 household investors those who have investments, were selected from the Virudhunagar District for data collection.

\section{Geographical Area of Study}

The survey was conducted in Virudhunagar District only. Virudhunagar District comprise of six Taluks namely Virudhunagar, Sattur, Sivakasi, Srivilliputhur, Rajapalayam and Arrupukkottai. Production of Crackers, Matches, and Pen nips, printing and edible oils are the major businesses in the district.

\section{Tools for Collection of Data and Pre-test}

To increase the effectiveness of the Interview schedule, prior to the actual survey, a Pre-test was conducted among 50 respondents. The minor modifications are made in the interview schedule on the basis of pre test. Then, the refined interview schedule was used as the data collection instrument in the actual survey. Data collection and the other field works are done by the researcher himself. It was carried out during the period of October 2013 to December 2013.

\section{Data Processing}

After the completion of survey, the filled in interview schedules had been edited properly to make it ready for coding. The respondent's responses to each questions in the schedule was posted in the Master table. Then, various tables are prepared for the purpose of analysis of data with the application of statistical tools. Percentage analysis, weighted average method and Chi-Square analysis are Statistical tools used for data analysis.

\subsection{Socio Economic Profile of the Household Investors}

The socio economic factors of the respondents like age, sex, education, occupation, monthly income, family income, size of the family are analyzed.
Table 1 shows the classification of the respondents on gender basis. Among 200 respondents, $81 \%$ of the respondents are Male and remaining 19\% of them are Female. Majority of the respondents are male members; they are taken for the study due to their availability and their awareness for various investments.

Table 2 shows the classification of the respondents on Age group basis. Among 200 respondents, $12 \%$ of the respondents are in the age group of $20-30 ; 24 \%$ of the respondents are in the age group of $30-40 ; 27 \%$ are in the age group of $40-50,21 \%$ of the respondents are in the age group of $50-60 ; 16 \%$ of the respondents are in age group of more than 60 . Most of the respondents are in the age group of 30-60.

Table 3 shows the classification of the respondents on the basis of their marital status. The marital status of the respondents has significant impact on their savings and investments. Only 7\% of the total respondents are unmarried. Rest of them that is $93 \%$ are married. Out of that $2.5 \%$ of total respondents are married; but they are either widow or widower.

Table 4 shows the classification of the respondents on the basis of their educational qualification. The education of the respondents has significant impact on their attitude and knowledge level. Out of 200 respondents, $32.5 \%$ are in secondary school level only. $28 \%$

Table 1. Gender wise classification of the respondents

\begin{tabular}{lcc}
\hline Gender & No of respondents & Percentage \\
\hline Male & 162 & 81 \\
Female & 38 & 19 \\
Total & 200 & 100 \\
\hline
\end{tabular}

Source: Primary data

Table 2. Age wise classification of the respondents

\begin{tabular}{lcc}
\hline Age & No of respondents & Percentage \\
\hline $20-30$ & 24 & 12 \\
$30-40$ & 48 & 24 \\
$40-50$ & 54 & 27 \\
$50-60$ & 42 & 21 \\
$>60$ & 32 & 16 \\
Total & 200 & 100 \\
\hline
\end{tabular}

Source: Primary data 
of the respondents are in higher secondary level. 15\% of them are graduates. Only $9 \%$ of them are post graduates. $15.5 \%$ of the respondents hold professional degree. Among 200 respondents, $60 \%$ of the respondents have not crossed the school level education.

Table 5 shows the classification of the respondents on the basis of their Occupation. The Occupation of the respondents has significant impact on their attitude, knowledge level and their preference. Out of 200 respondents, $31 \%$ are government employees. $11.5 \%$ of the respondents are pensioners. Only $6 \%$ of them are private employees. $41 \%$ of the respondents are in Business. And $10.5 \%$ of the respondents are professionals.

Table 6 shows the classification of the respondents on the basis of their Family type. The Family type of the

Table 3. Marital Status wise classification of the respondents

\begin{tabular}{lcc}
\hline Marital status & No of respondents & Percentage \\
\hline Unmarried & 14 & 7 \\
Married & 181 & 90.5 \\
Widow/ Widower & 5 & 2.5 \\
Total & 200 & 100 \\
\hline Source:Primary data & &
\end{tabular}

Source: Primary data

Table 4. Education wise classification of the respondents

\begin{tabular}{lcc}
\hline Educational qualification & No of respondents & Percentage \\
\hline Up to $10^{\text {th }}$ & 65 & 32.5 \\
Up to $12^{\text {th }}$ & 56 & 28 \\
Degree & 30 & 15 \\
PG & 18 & 9 \\
Professional & 31 & 15.5 \\
Total & 200 & 100 \\
\hline
\end{tabular}

Source: Primary data

Table 5. 0ccupation wise classification of the respondents

\begin{tabular}{lcc}
\hline Occupation & No of respondents & Percentage \\
\hline Government employees & 62 & 31 \\
Pensioners & 23 & 11.5 \\
Private employees & 12 & 6 \\
Business & 82 & 41 \\
Professionals & 21 & 10.5 \\
Total & 200 & 100 \\
\hline
\end{tabular}

Source: Primary data respondents has significant impact on their savings and investments. Out of 200 respondents, $87 \%$ are following the nuclear family system. Remaining $13 \%$ of the respondents are following the Joint family system. Most of the respondents are following the nuclear family system.

\subsection{Investment Attitude of Households}

The attitude of household in investment is studied through raising questions and getting answers on the same. The discussion with households and the analysis are given here.

Table 7 shows the deciders of investment decision of respondents. $49 \%$ of the total respondents have decided their investment decision themselves. They do not consult with other members of their family. $6 \%$ of the respondents said that investment decision is made by their spouse. $29.5 \%$ of the respondents use to consult with their spouse to decide their investment decision. Figure 1 also shows the deciders of investment decision $12 \%$ of the respondents use to consult with elders of their family to decide their investment decision. Only $3.5 \%$ of the respondents said that investment decision is made by elders of their family. Most of the time, investment decision is made by the respondents.

Table 8 shows the investor's source of investment. It shows the investor's way of raising the money for his/

Table 6. Family Type wise classification of the respondents

\begin{tabular}{lcc}
\hline Family type & No of respondents & Percentage \\
\hline Nuclear & 174 & 87 \\
Joint & 26 & 13 \\
Total & 200 & 100 \\
\hline
\end{tabular}

Source: Primary data

Table 7. Deciders of Investment Decision

\begin{tabular}{lcc}
\hline Deciders & No of respondents & Percentage \\
\hline Self & 98 & 49 \\
Spouse & 12 & 6 \\
Consultation with spouse & 59 & 29.5 \\
Consultation with elders & 24 & 12 \\
Elders & 7 & 3.5 \\
Total & 200 & 100 \\
\hline
\end{tabular}

Source: Primary data 


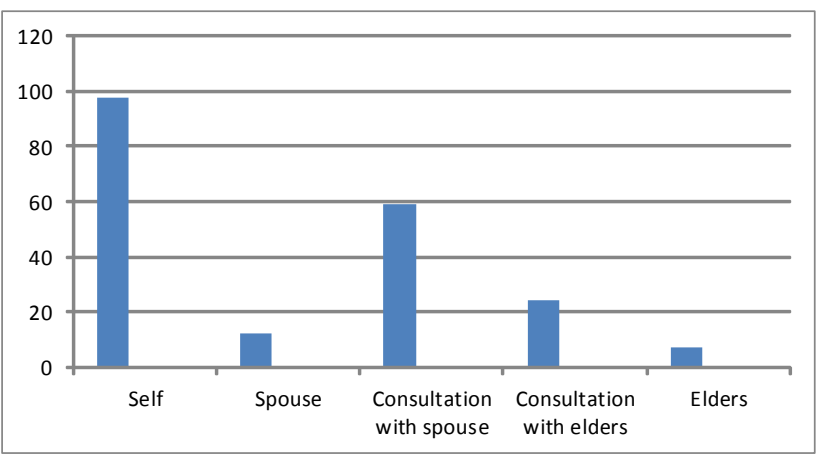

Figure 1. Deciders of Investment Decision.

Table 8. Source of Investment

\begin{tabular}{lcc}
\hline Source of investment & No of respondents & Percentage \\
\hline Savings & 104 & 52 \\
Other earnings & 86 & 43 \\
Part of regular income & 10 & 5 \\
Total & 200 & 100 \\
\hline
\end{tabular}

Source: Primary data

her investment. Source of investment may be Savings, which is investor set aside some portion of his/ her regular income as savings for future investment. Or it may be other earnings such as bonus etc. This extra income apart from his/ her regular monthly income is utilized for his/ her investment. Some times the investor may not be able to save regularly from his monthly income. So at once, the investor makes investment from his/ her regular monthly income. Out of 200 respondents, 52\% use savings as their source of investment. $43 \%$ of the respondents use their other earnings as their source of investment. Only $5 \%$ of the respondents use their part of regular monthly income as their source of investment. Figure 2 also shows Source of investment.

Table 9 shows the classification of the respondents on the basis of their regularity towards their Investments. Some investors may be regular investors. They have the habit of making investment regularly. Others occasionally make investments. They are called as Occasional Investors. Out of 200 respondents, $44.5 \%$ are regular investors. Remaining $55.5 \%$ of the respondents are Occasional Investors. Figure 3 also shows the investor type on the basis of regularity of investment.

Table 10 shows the classification of the respondents on the basis of their willingness to bear a level of risk

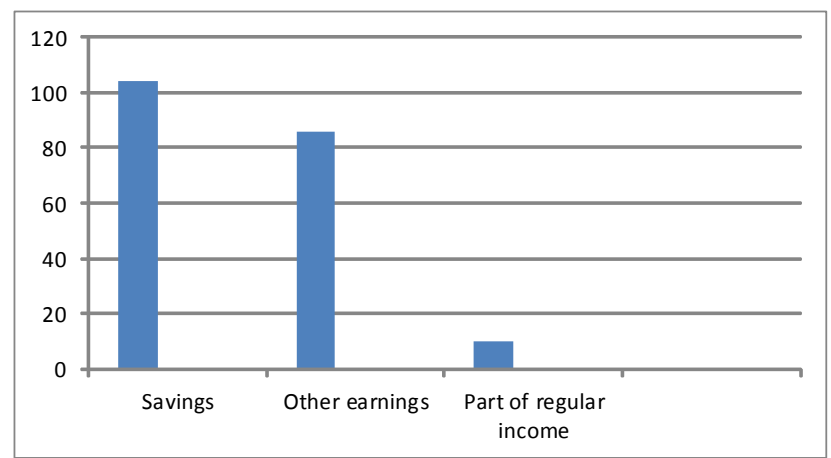

Figure 2. Source of Investment.

Table 9. Investor type on the basis of Regularity of Investment

\begin{tabular}{lcc}
\hline Type of investor & No of respondents & Percentage \\
\hline Regular & 89 & 44.5 \\
Occasional & 111 & 55.5 \\
Total & 200 & 100 \\
\hline
\end{tabular}

Source: Primary data

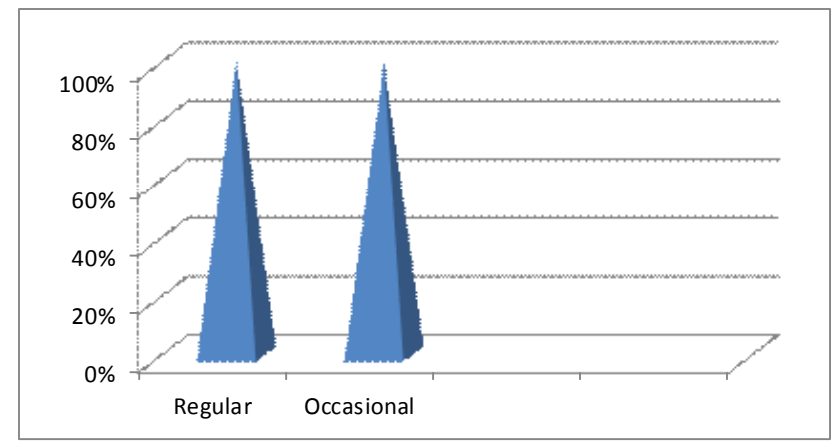

Figure 3. Investment Type.

Table 10. Investor type on the basis of level of risk that investor willing to bear

\begin{tabular}{lcc}
\hline Risk Type & No of respondents & Percentage \\
\hline Risk averters & 102 & 51 \\
Risk neuters & 81 & 40.5 \\
Risk Takers & 17 & 8.5 \\
Total & 200 & 100 \\
\hline
\end{tabular}

Source: Primary data

towards their Investments. Investors can be classified in to three types based on the level of risk an investor is willing to bear in his/ her investments. They are Risk Averters, Risk Neuters and Risk Takers.

An investor who is willing to keep the risk at the bay in their investment is called as risk averters. They give 
more importance to safety over return potential of their investment. Their investment approach focuses on preservation of capital. This can be achieved by investing in low risk securities, albeit at the cost of a relatively low return potential. An investor who is ready to bear high level of risk in their investments against the possibility of return potential of that investment is called as Risk takers. Their investment approach accords the highest priority to earning returns, even as the risk undertaken to generate these returns may be commensurately higher. An investor who is willing to bear the level of risk in between that of risk averters and risk takers is called as Risk Neuters. Figure 4 also shows the investor type on the basis of level of risk that investor willing to bear Out of 200 respondents, $51 \%$ investors are risk aversive investors. $40.5 \%$ investors are risk neuters. Only $8.5 \%$ investors are risk takers.

Table 11 shows the current investments of investors in various investment alternatives. Bank deposits,

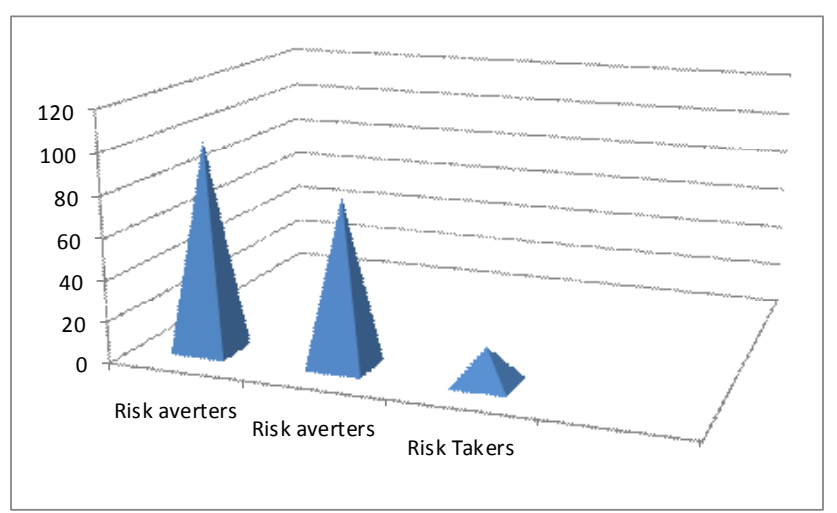

Figure 4. Type of Investors on the Basis of Level of Risk.

Table 11. Current Investments in various investment types

\begin{tabular}{lll}
\hline Investment types & No of respondents & Percentage \\
\hline Bank Deposits & 63 & 31.5 \\
Insurance & 170 & 85 \\
Post office schemes & 72 & 36 \\
Shares & 10 & 5 \\
Mutual funds & 20 & 10 \\
Bonds/debentures & 4 & 2 \\
Chits & 132 & 66 \\
\hline
\end{tabular}

Source: Primary data

Note: Total number of responses outnumbers the total number of respondents. Because one respondent has given more than one response.
Insurance, Post Office Schemes, Shares, Mutual Funds, Bonds and Chits are the various investment alternatives to the investors. Apart from this, Gold / Silver and Real estate are other alternatives. Since those real assets investments are known to every one they are omitted from analysis. $31.5 \%$ of total respondents have invested in Bank Deposits. 85\% of total respondents have invested in various Insurance policies. 36\% of total respondents have invested in various Post Office Schemes. Only 5\% of total respondents have invested in Shares. $10 \%$ of total respondents have invested in Mutual Funds. Just $2 \%$ of total respondents have invested in Bonds. $66 \%$ of total respondents have invested in Chits. Figure 5 also shows the current investments of households.

Table 12 shows the current investment level of investors in various investment alternatives. Many investors

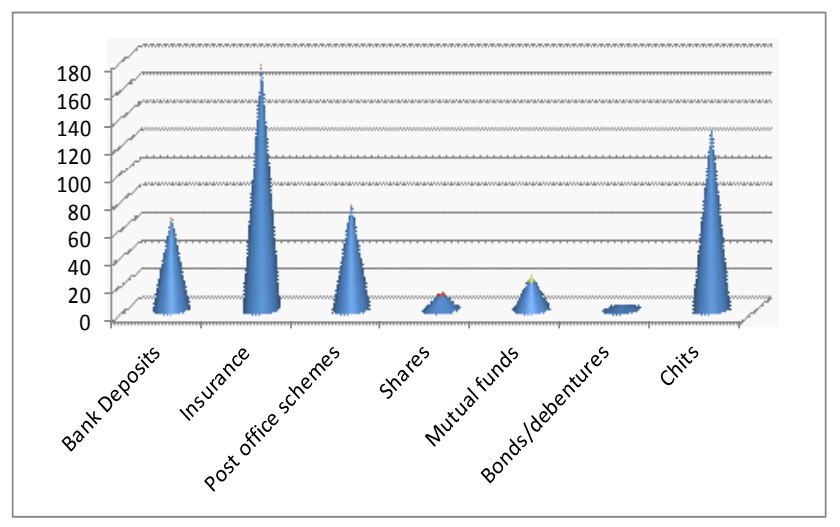

Figure 5. Current Investments.b

Table 12. Level of Investments made currently in various investment types

\begin{tabular}{|c|c|c|c|c|c|c|c|c|}
\hline \multirow{2}{*}{$\begin{array}{l}\text { Investment } \\
\text { type }\end{array}$} & \multicolumn{7}{|c|}{ Investment level } & \multirow{2}{*}{ Total } \\
\hline & $<5000$ & $\begin{array}{l}5000- \\
10000\end{array}$ & $\begin{array}{l}10000- \\
20000\end{array}$ & $\begin{array}{l}20000- \\
30000\end{array}$ & $\begin{array}{l}30000- \\
50000\end{array}$ & $\begin{array}{l}50000- \\
100000\end{array}$ & $>100000$ & \\
\hline $\begin{array}{l}\text { Bank } \\
\text { Deposits }\end{array}$ & 3 & 16 & 15 & 10 & 9 & 6 & 4 & 63 \\
\hline Insurance & 0 & 2 & 4 & 1 & 132 & 19 & 12 & 170 \\
\hline $\begin{array}{l}\text { Post office } \\
\text { Scheme }\end{array}$ & 11 & 20 & 9 & 12 & 15 & 3 & 2 & 72 \\
\hline Shares & 7 & 2 & 1 & 0 & 0 & 0 & 0 & 10 \\
\hline $\begin{array}{l}\text { Mutual } \\
\text { funds }\end{array}$ & 0 & 4 & 7 & 9 & 0 & 0 & 0 & 20 \\
\hline $\begin{array}{l}\text { Bonds/ } \\
\text { debentures }\end{array}$ & 0 & 0 & 2 & 2 & 0 & 0 & 0 & 4 \\
\hline Chits & 27 & 36 & 29 & 20 & 13 & 4 & 3 & 132 \\
\hline Total & 48 & 80 & 67 & 54 & 169 & 32 & 21 & \\
\hline
\end{tabular}

Source: Primary data 
have invested in Insurance policies and Chits. And their investment level in these alternatives is reasonably high when compared to other investments.

Only few investors have invested in Shares, Mutual Funds and Bonds. Though they have invested in these alternatives, their investment level in these alternatives is very low. No one investor has invested more than Rs. 30,000 in any of these alternatives. Bank deposits and Post Office Schemes are less risky and less return investments. Considerable level of investments is made in these alternatives. 21 respondents have invested more than 1,00,000 rupees. Out of those 21 respondents, many of them have invested in Insurance and Bank deposits.

\subsection{Investment Preference}

There are various investment avenues available like stocks, bonds, bank fixed deposits, post office schemes, mutual funds, and insurance etc. Investor can design a portfolio of various investment instruments to meet their financial goals. The choice among the various options depends on investor's liquidity needs, investment horizon, risk appetite and return expectations. These in turn, are determined by investor's personal circumstances and other factors like age, standard of living and their future financial commitments. Based on the investor's investment approach there are three types of investors: conservative, moderate, and aggressive. Conservative investors focus on preservation of capital. They invest in low risk securities, albeit at the cost of a relatively low return potential. This means that they put their money in interest bearing savings accounts, mutual funds, and Certificates of Deposit.

Moderate investors are willing to accept a moderately higher level of risk, to earn higher returns as compared to a conservative investor. This strategy primarily focuses on achieving higher risk adjusted returns. Aggressive investors accord the highest priority to earning returns, even as the risk undertaken to generate these returns may be commensurately higher. They commonly do most of their investing in the stock market, which is higher risk.

Table 13 shows the ranks given by the respondents for various investment types based on their preference.
Bank Deposits, Insurance Policies, Post Office Schemes, Shares, Mutual Funds, Bonds and Chits are the various investment types.

Majority of the respondents have given first rank for Bank Deposits. Next to Bank Deposits, Chits, Insurance Policies and Post Office Schemes are preferred by many investors. Only very few investors have given top priority to Shares, Mutual Funds and Bonds.

Table 14 shows the weightages applied to the various ranks for investment types.

Table 15 shows the weighted score for the various ranks given by the respondents for various investment types, when weightages applied as per Table 16.

Table 13. Table showing Ranks given by respondents for various Investment types

\begin{tabular}{lcccccccc}
\hline Investments & \multicolumn{7}{c}{ Ranks } & Total \\
\cline { 2 - 7 } & 1 & 2 & 3 & 4 & 5 & 6 & 7 & \\
\hline Bank Deposit & 106 & 51 & 19 & 13 & 8 & 2 & 1 & 200 \\
Insurance & 29 & 23 & 51 & 41 & 33 & 16 & 7 & 200 \\
Post 0ffice & 22 & 63 & 43 & 26 & 21 & 20 & 5 & 200 \\
Scheme & & & & & & & & \\
Share & 2 & 8 & 19 & 40 & 50 & 48 & 33 & 200 \\
Mutual Fund & 1 & 6 & 21 & 30 & 33 & 62 & 47 & 200 \\
Bonds & 1 & 2 & 5 & 11 & 38 & 41 & 102 & 200 \\
Chits & 39 & 47 & 42 & 39 & 17 & 11 & 5 & 200 \\
Total & 200 & 200 & 200 & 200 & 200 & 200 & 200 & \\
\hline
\end{tabular}

Source: Primary data

Table 14. Table showing the weightages applied to various ranks

\begin{tabular}{llllllll}
\hline Rank & 1 & 2 & 3 & 4 & 5 & 6 & 7 \\
\hline Weightage & 7 & 6 & 5 & 4 & 3 & 2 & 1 \\
\hline
\end{tabular}

Table 15. Table showing the weighted and Total weighted score given by the respondents for various Investment types

\begin{tabular}{|c|c|c|c|c|c|c|c|c|}
\hline \multirow[t]{2}{*}{ Investments } & \multicolumn{7}{|c|}{$\%$} & \multirow{2}{*}{$\begin{array}{c}\text { Total } \\
\text { Weighted } \\
\text { Score }\end{array}$} \\
\hline & 1 & 2 & 3 & 4 & 5 & 6 & 7 & \\
\hline Bank Deposit & 742 & 306 & 95 & 52 & 24 & 4 & 1 & 1224 \\
\hline Insurance & 203 & 138 & 255 & 164 & 99 & 32 & 7 & 898 \\
\hline $\begin{array}{l}\text { Post Office } \\
\text { Scheme }\end{array}$ & 154 & 378 & 215 & 104 & 63 & 40 & 5 & 959 \\
\hline Share & 14 & 48 & 95 & 160 & 150 & 96 & 33 & 596 \\
\hline Mutual Fund & 7 & 36 & 105 & 120 & 99 & 124 & 47 & 538 \\
\hline Bonds & 7 & 12 & 25 & 44 & 114 & 82 & 102 & 386 \\
\hline Chits & 273 & 282 & 210 & 156 & 51 & 22 & 5 & 999 \\
\hline
\end{tabular}

Source: Primary data 
Table 16 shows the overall rank and total weighted score for the various investment types based on the respondent's preference. Bank Deposit has got the maximum total weighted score. So Bank Deposit has been given the overall first rank. Investment in Chits is given second rank. Post Office Scheme is given the third rank. Insurance Policies, Shares and Mutual Funds are given fourth, fifth and the sixth rank respectively. Bonds are given the last rank.

\subsection{Influencing Factors of Investment}

Table 17 shows the ranks given by the respondents for various influencing factors towards investment. Return potential, Capital appreciation, Safety, Tax benefits, Liquidity, Hedge against inflation and Convenience are the various influencing factors towards investment.

Majority of the respondents have given first rank for Safety. Next to safety, Return potential and Liquidity

Table 16. Table showing the Overall Rank and the Total weighted score given by respondents for various Investment types

\begin{tabular}{lcc}
\hline Investments & Total weighted score & Overall Rank \\
\hline Bank Deposit & 1224 & 1 \\
Insurance & 898 & 4 \\
Post Office Scheme & 959 & 3 \\
Share & 596 & 5 \\
Mutual Fund & 538 & 6 \\
Bonds & 386 & 7 \\
Chits & 999 & 2 \\
\hline
\end{tabular}

Source: Computed Data

Table 17. Ranking of the Factors Influencing investment

\begin{tabular}{lcccccccc}
\hline Factors & \multicolumn{9}{c}{ Ranks } & Total \\
\cline { 2 - 7 } & 1 & 2 & 3 & 4 & 5 & 6 & 7 & \\
\hline Return potential & 41 & 38 & 39 & 37 & 30 & 11 & 4 & 200 \\
Capital & 20 & 24 & 25 & 22 & 37 & 30 & 42 & 200 \\
appreciation & & & & & & & & \\
Safety & 82 & 43 & 36 & 19 & 11 & 7 & 2 & 200 \\
Tax benefits & 3 & 14 & 34 & 22 & 23 & 20 & 84 & 200 \\
Liquidity & 39 & 42 & 29 & 31 & 27 & 25 & 7 & 200 \\
Hedge against & 6 & 16 & 12 & 30 & 35 & 71 & 30 & 200 \\
inflation & & & & & & & & \\
Convenience & 9 & 23 & 25 & 39 & 37 & 36 & 31 & 200 \\
Total & 200 & 200 & 200 & 200 & 200 & 200 & 200 & 200 \\
\hline
\end{tabular}

Source: Primary data are preferred by many investors. Only very few investors have given top priority to Tax benefits, Hedge against Inflation and Convenience.

Table 18 shows the weightages applied to the various ranks for influencing factors towards investment.

Table 19 shows the weighted score for the various ranks for influencing factors towards investment when weightages applied as per Table 20.

Table 20 shows the overall rank and total weighted score for the various influencing factors towards investment. Safety has got the maximum total weighted score. So Safety has been given the overall first rank.

Table 18. Table showing the weightages applied to various ranks

\begin{tabular}{llllllll}
\hline Rank & 1 & 2 & 3 & 4 & 5 & 6 & 7 \\
\hline Weightage & 7 & 6 & 5 & 4 & 3 & 2 & 1 \\
\hline
\end{tabular}

Table 19. Table showing the weighted scores for various influencing factors towards investment

\begin{tabular}{lcccccccc}
\hline Factors & \multicolumn{7}{c}{ Rank } & $\begin{array}{c}\text { Total weighted } \\
\text { score }\end{array}$ \\
\cline { 2 - 7 } & 1 & 2 & 3 & 4 & 5 & 6 & 7 & 974 \\
\hline $\begin{array}{l}\text { Return } \\
\text { potential }\end{array}$ & 287 & 228 & 195 & 148 & 90 & 22 & 4 & \\
$\begin{array}{l}\text { Capital } \\
\text { appreciation }\end{array}$ & 140 & 144 & 125 & 88 & 111 & 60 & 42 & 710 \\
$\begin{array}{l}\text { Safety } \\
\text { Tax benefits }\end{array}$ & 21 & 84 & 170 & 88 & 69 & 40 & 84 & 556 \\
Liquidity & 273 & 252 & 145 & 124 & 81 & 50 & 7 & 932 \\
Hedge against & 42 & 96 & 60 & 120 & 105 & 142 & 30 & 595 \\
inflation & & & & & & & & \\
Convenience & 63 & 138 & 125 & 156 & 111 & 72 & 31 & 696 \\
\hline
\end{tabular}

Source: Computed Data

Table 20. Table showing the Overall Rank for various influencing factors towards investment

\begin{tabular}{lcc}
\hline Factors & Total weighted score & Overall Rank \\
\hline Return potential & 974 & 2 \\
Capital appreciation & 710 & 4 \\
Safety & 1137 & 1 \\
Tax benefits & 556 & 7 \\
Liquidity & 932 & 3 \\
Hedge against inflation & 595 & 6 \\
Convenience & 696 & 5 \\
\hline
\end{tabular}

Source: Computed Data 
Return potential is given second rank. Liquidity is given third rank. Capital appreciation, convenience and Hedge against inflation are given fourth, fifth and sixth ranks respectively. Tax benefit is given the last rank.

\subsection{Chi - Square Analysis}

Chi square analysis is made to find the association between socio economic factors of the respondents and influencing factors towards their investment.

Chi Square Value $=\sum\left[(\mathrm{O}-\mathrm{E})^{2} / \mathrm{E}\right]$

Degrees of Freedom $=($ Number of rows -1$) *$

$$
\text { (Number of coloumns -1) }
$$

\section{Decision Criteria}

- Do not reject Ho if the Calculated Value is less than the Table Value otherwise reject the Ho

- For the purpose of this analysis the following hypothesis is framed

$\mathrm{H}_{0}$ : There is no significant relationship between Socio Economic status of the respondents and the influencing factor of investment

$\mathrm{H}_{1}$ : There is significant relationship between Socio Economic Status of the respondents and the influencing factor of investment

According to Chi Square Test, there is a significant relationship between the education and influencing factors, monthly income and influencing factors and Family Income and Influencing Factors. (Table 21)

Table 21. Chi-Square Results

\begin{tabular}{llcccc}
\hline $\begin{array}{l}\text { S. } \\
\text { No. }\end{array}$ & Factors & $\begin{array}{c}\text { Calculated } \\
\text { Value }\end{array}$ & $\begin{array}{c}\text { Degrees of } \\
\text { Freedom }\end{array}$ & $\begin{array}{c}\text { Table Value } \\
\text { at } \\
5 \% \text { Level }\end{array}$ & Result \\
\hline 1 & $\begin{array}{l}\text { Age and Influencing } \\
\text { Factors }\end{array}$ & 17.38 & 24 & 36.415 & Not Significant \\
2 & 40.79 & 24 & 36.415 & Significant \\
$\begin{array}{l}\text { Education and } \\
\text { Influencing } \\
3\end{array}$ & 33.86 & 24 & 36.415 & Not Significant \\
$\begin{array}{l}\text { Factors } \\
\text { Occupation and } \\
\text { Influencing }\end{array}$ & & & & & \\
4 & $\begin{array}{l}\text { Factors } \\
\text { Monthly Income and } \\
\text { Influencing Factors }\end{array}$ & 86.27 & 30 & 43.773 & Significant \\
5 & $\begin{array}{l}\text { Family Income and } \\
\text { Influencing Factors }\end{array}$ & 71.23 & 30 & 43.773 & Significant \\
\hline Source: Computed Data & & & & \\
\hline
\end{tabular}

Source: Computed Data

\section{Findings of the Study}

The findings inferred from the statistical analysis of frequency tables of this study are summarized below.

\subsection{Socio Economic Profile of Respondents}

- Among 200 respondents, $81 \%$ are Male and remaining $19 \%$ are Female.

- Among 200 respondents, $12 \%$ are in the age group of $20-30 ; 24 \%$ are in the age group of $30-40 ; 27 \%$ are in the age group of $40-50 ; 21 \%$ are in the age group of $50-60 ; 16 \%$ are in the age group of more than 60.

- Only $7 \%$ of the total respondents are unmarried. $90.5 \%$ are married. $2.5 \%$ are widow / widower.

- $60 \%$ of the respondents have not crossed the school level education. $15 \%$ are graduates. Only $9 \%$ of them are post graduates. $15.5 \%$ hold professional degree.

- $31 \%$ are government employees. $12.5 \%$ are pensioners. Only $6 \%$ are private employees. $41 \%$ are in Business. And 10.5\% are professionals.

- Only 3\% respondents have the monthly income less than Rs. $10,000.48 .5 \%$ have the monthly income of Rs. $10,000-20,000.35 .5 \%$ have the monthly income of Rs. 20,000-30,000.

- $10 \%$ have the monthly income of Rs. 30,000-40,000. Only $2.5 \%$ have the monthly income of Rs. 40,000 50,000 . Just $0.5 \%$ has monthly income of more than Rs. 50,000 .

- Out of 200 respondents, only $1 \%$ has the monthly family income of less than Rs. 10,000. 49.5\% have the monthly family income of Rs. 10,000-20,000. $35 \%$ have the monthly family income of Rs. $20,000-$ 30,000 .

- Most of the time, investment decision is made by the respondents. $49 \%$ of the total respondents do not consult with other members of their family.

- $6 \%$ said that investment decision is made by their spouse. Only 3.5\% said that investment decision is made by elders of their family.

- $29.5 \%$ use to consult with their spouse to decide their investment decision. $12 \%$ use to consult with elders of their family.

- Out of 200 respondents, $52 \%$ use savings as their source of investment. $43 \%$ use other earnings and 
only $5 \%$ use their part of regular monthly income as the source of investment.

- $44.5 \%$ respondents are regular investors. Remaining are Occasional Investors.

- $51 \%$ investors are risk aversive investors. $40.5 \%$ are risk neuters. Only $8.5 \%$ are risk takers.

\subsection{Investments and Level of Investment}

- 63 respondents (31.5\%) have invested in Bank Deposits. 170 respondents $(85 \%)$ have invested in various Insurance policies. 72 respondents $(36 \%)$ have invested in Post Office Schemes. Only $10(5 \%)$ have invested in Shares. 20 (10\%) have invested in Mutual Funds. Just 4 respondents $(2 \%)$ have invested in Bonds. 132 respondents (66\%) have invested in Chits.

- Many investors have invested in Insurance policies and Chits. And their investment level in these alternatives is reasonably high when compared to other investments.

- Only few investors have invested in Shares, Mutual Funds and Bonds. Though they have invested in these alternatives, their investment level is very low.

- Considerable level of investments is made in Bank deposits and Post Office Schemes.

\subsection{Influencing Factors towards Investment}

Among the various influencing factors towards investment, Safety has been given the first rank. Return potential is given second rank. Liquidity is given third rank. Capital appreciation, convenience and Hedge against inflation are given fourth, fifth and sixth rank respectively. Tax benefit is given last rank.

\subsection{Chi-square Test Result}

According to Chi Square Test, there is a significant relationship between the education and influencing factors, monthly income and influencing factors and Family Income and Influencing Factors.

\section{Suggestions}

After having analyzed the investment knowledge of household investors in the Virudhunagar District, the researcher offers the following suggestions in connection with the present study.

- As most of the respondents invested in insurance only, Steps should be taken to create awareness among the household investors about all the investment avenues.

- The majority of the respondents come to know about the various schemes through the friends and agents. Therefore it is recommended to various financial institutions to adopt a broad advertising strategy to create awareness among household investors in this region.

- Most of the respondents follow the conservative approach towards the investment. So they are not willing to invest in stocks. Anyway mutual funds offers more return to the investors with sufficiently lower risk level. So investors can invest in this avenue.

- Investor first understand his investment objective and analyze the various investment avenues. Then investor can choose the best avenue exactly to suit to his needs.

- As mutual funds place the $6^{\text {th }}$ rank, the advertisements about mutual funds are not reached the general public sufficiently. Therefore, the mutual fund companies should appoint large number of agents, like insurance companies, to popularize the schemes of mutual fund among public.

- As the factor safety place first rank the government should ensure the safety of money invested in various investment avenues.

- As the socio economic factors education and income have influencing relationship on investment, the government and concerned investment organization, they should restructure their programme to different educational and income group of people.

\section{Conclusion}

The behavior analysis on investment of households in Virudhunagar district is analysed through this study. The households prefer bank deposits mostly and dislike shares and mutual funds. The factor safety influenced more on investment decision of households and the socio economic factors education and income 
have relationship with investment of household. On the basis of the findings, the researcher presents suggestions for better investment decision of the household. If the suggestions are carried out definitely, which lead to better behavior on investment.

\section{References}

Avadhani, V. A. (1998). Investment Management. Bombay: Himalaya Publishing House.

Abhijeet, C. \& Ravinder, K. (2011). Determinants of Individual Investor Behavior: An Orthogonal Linear Transformation Approach. Available at http://mpra. ub.uni-muenchen.de/29722/MPRA Paper No. 29722, posted 22. March 2011 16:11 UTC.

Chaturvedi, M., \& Khare, S. (2012). Study of saving pattern and investment preferences of individual household in India. International Journal of Research in Commerce and Management. 3(5), 115-120.

Davar, Y. P., \& Gill, S. (2009). Antecedents of households' investment decision-making process: A study of the Indian households. South Asian Journal of Management, 16(4), 44-75.

Gupta, S. P. (2011). Statistical Methods. New Delhi: Sultan Chand and Sons.

Gupta, L. C., Gupta, C.P., \& Jain, N. (2001). Indian Households' Investment Preferences: A Survey. Society of Capital Market Research and Development. New Delhi: Alankrit Printers.

Gupta, L. C., \& Jain, N. (2008). Indian Households' Investment Preferences: The Third All India investors' Survey. Society for Capital Market Research and Development.

Geetha, N., \& Ramesh, M. (2011). A study of people's preferences in investment behavior. IJEMR, 1(6), 1-10.

Josiah, A., Odera, E. O., \& Mactosh, O. (2012). The Behavior and Financial Performance of Individual Investors in the Trading Shares of Companies Listed At the Nairobi Stock Exchange, Kenya. Journal of Finance and Investment Analysis, 1(3), 33-60.

Kothari, C. R. (2003). Research Methodology. New Age International Publishers.

Kim, K. A., \& John, R. N. (2003). The Behavior and Performance of Individual Investors in Japan.

Leon, G. S., \& Leslie L. K. (2003). Consumer Behavior. New Delhi: Prentice Hall of India.

Lubna, A., \& Sana, M. (2013). Factors Affecting Investment Behavior among Young Professionals. International Journal of Technical Research and Applications, 1(2), 27-32.
Murithi, S. S., Narayanan, B., \& Arivazhagan, M. (2012). Investors Behavior in Various Investment Avenues A Study. International Journal of Marketing and Technology, 2, 36-45.

Mandeep, K. \& Tina, V. (2012). Understanding Individual Investor's Behavior: A Review of Empirical Evidences. Pacific Business Review International. 5(6), 10-18.

Nagy, R. A. \& Obenberger R. W. (1994). Factors Influencing Investors Behavior. Financial Analyst Journal, 50, 63-68.

Philip, K. (2003). Marketing Management. Delhi: Pearson Education.

Preethi, S. (1998). Investment Management. Bombay: Himalaya Publishing House.

Puneet, B. (2014). Insights into Awareness Level and Investment Behavior of Salaried Individuals towards Financial Products. International Journal of Engineering, Business and Enterprise Applications, 8(1), 53-57.

Saloni, R. \& Bhuvan, L. (2013). Behavior of Investors towards Investment. Indian Journal of Applied Research, $3(10), 1-2$.

Shahbaz, N. \& Mahmood, K. (2004). Saving-investment Behavior in Pakistan: An Empirical Investigation. The Pakistan Development Review. 43(4), 665-682.

Shanmuga, S. V. \& Bala, K. V. (2011). Investment decisionmaking - a behavioral approach. International Journal of Business innovation \& Research, 4(6), 432-444.

Suman, C. \& Sabat, K. D. A Study of Saving and Investment Behavior of Individual Households - An Empirical Evidence from Orissa.

\section{About the Authors}

Dr. M. Selvakumar is presently working as Assistant Professor of Commerce in Ayya Nadar Janaki Ammal College, Sivakasi, India. He has more than two decade of experience in education. He completed his doctorate degree from Madurai Kamaraj University in the year 2008 and MBA Degree from IGNOU, New Delhi. His area of interest is Banking and Finance. He is the author of more than 150 research articles in national and international reputed journals like Vinimaya, Kurukshetra, Economic Affairs, Southern Economist, Social and Economic Thoughts etc. He has completed two research projects funded by University Grants Commission, India and also guided $3 \mathrm{Ph}$.Ds and 30 M.Phil Scholars. At present 8 Ph.D Scholars and 3 M.Phil Scholars are doing research under his supervision. 
Dr. N. Manicka Mahesh is a Post Graduate Rank holder in commerce and completed doctoral degree from Madurai Kamaraj University affiliated college. He has qualified in lectureship exam (SLET) State level Educational Testing and (NET) National Educational Test during the year 2000. He has qualified intermediate in the renowned professional course from ICWAI, (Institute of Cost and Works Accountants of India) Calcutta. He has more than a decade of experience in teaching and couple of years in industry. Apart from collegiate teaching, the author used to handle the face to face interaction sessions for employees of the leading private banks like ICIC bank. He has published more articles in the national level journals and participated in several workshop, presented papers in the seminars and conferences. His area of specialization is finance and having a good exposure in the domain of Security Analysis and Portfolio Management. He is a member of All India Management association and Coimbatore Management Association and used to participate in the CII (Confederation of Indian Industry) conference at regular intervals. 